http://dx.doi.org/10.11646/phytotaxa.158.3.5

\title{
Three new species of Stelis (Orchidaceae; Pleurothallidinae) from Mexico
}

\section{RODOLFO SOLANO GOMEZ}

Instituto Politecnico Nacional, Centro Interdisciplinario de Investigacion para el Desarrollo Integral Regional Unidad Oaxaca, Hornos 1003, Santa Cruz Xoxocotlan, 7230, Oaxaca, Mexico; E-mail: solanogo@yahoo.com.mx

\begin{abstract}
Three new species in the genus Stelis (Orchidaceae) are here described and illustrated for the first time: two have been previously mentioned and are published formally here. For each taxon, information is provided about its distribution, habitat, phenology, traits that distinguish it from similar species, and conservation status. A line drawing, photo, and map for the known localities of the three species are provided.
\end{abstract}

Key words: Orchids, Stelis guerrerensis, Stelis kaiae, Stelis lapinerae.

Resumen. Se describe e ilustra por primera vez tres nuevas especies en el género Stelis (Orchidaceae): dos habían sido mencionadas previamente como nombres no publicados y aquí son formalmente publicados. Para cada taxon se proporciona información acerca de su distribución, hábitat, fenología, rasgos que la distinguen de especies similares, así como su estatus de conservación. Se proporciona un dibujo a línea, foto y mapa para las localidades conocidas de las tres especies aquí descritas.

Palabras clave: orquídeas, Stelis guerrerensis, Stelis kaiae, Stelis lapinerae

\section{Introduction}

The genus Stelis Swartz (1799: 239), with approximately 900 species in its narrower circumscription, according to Luer $(2007,2009)$ and almost 1100 in its broadest circumscription sensu Pridgeon et al. $(2001,2002,2005)$, is one of the largest genera in Orchidaceae, comparable in species richness to genera such as Bulbophyllum Thouars (1822: Table 3), Dendrobium Swartz (1799: 82), Epidendrum Linnaeus (1763: 952), and Lepanthes Swartz (1799: 85). The species of Stelis have their greatest richness in the Andes, especially in Colombia, Ecuador, and Peru. The genus is taxonomically difficult because botanists have traditionally neglected it, and currently there are few systematists specializing in it.

In Mexico, 60 species and one subspecies of Stelis have been recorded and formally published (Hagsater \& Soto Arenas, 2003, 2008; Solano, 1993, 2000, 2010, 2011; Solano \& Salazar, 2007; Soto Arenas et al., 2007; Ramos-Castro et al., 2012). Nonetheless, in recent years the continuous review of Mexican specimens in this group has led to the discovery of taxa that have not been formally named and described; three of them are described for the first time here. One was recently discovered in Chiapas, and the other two species had been mentioned in the literature but were not formally published (Soto et al., 2007; Szeszko, 2011). As a result of this, the number of Mexican taxa of Stelis sensu lato increases to 63 species and one subspecies.

\section{Taxonomy}

Stelis guerrerensis Soto Arenas \& R.Solano, sp. nov. (Figs. 1, 4A)

Similar to Stelis pachyglossa (Lindl.) Pridgeon \& M.W.Chase from which it differs by its smaller and caespitose habit, arching inflorescence, smaller flowers, lateral sepals united with each other to their apices, and distribution.

Type:-MEXICO. Guerrero: municipio Atoyac de Alvarez, El Molote, selva perennifolia de montaña, ca. $1600 \mathrm{~m}$ elev., prensado de material cultivado, 18 Sep. 2006, Santiago in Salazar 6739 (MEXU!). 


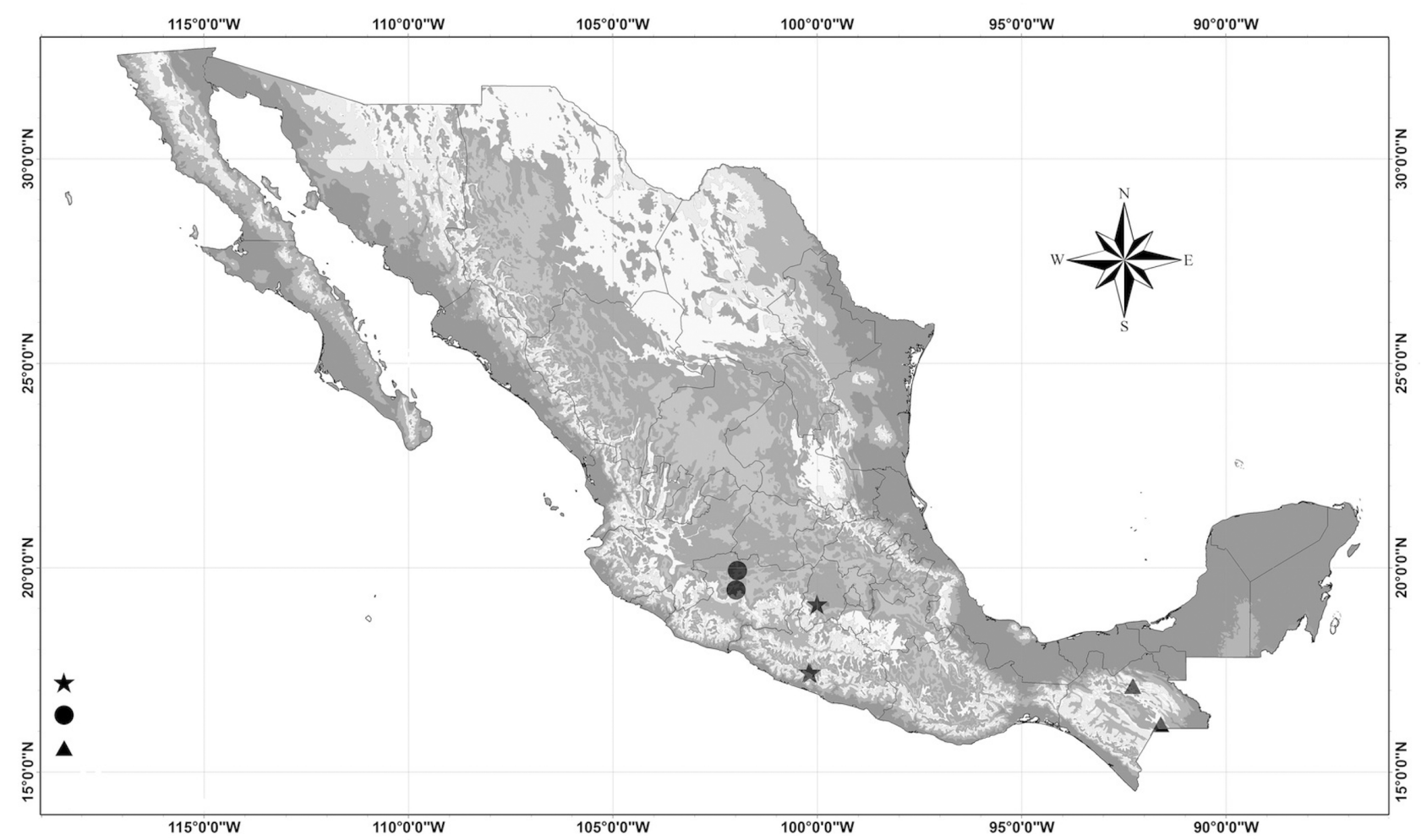

FIGURE 5. Map for known localities of Stelis guerrerensis (black star), Stelis kaiae (black triangle), and Stelis lapinerae (black circle).

\section{References}

Hagsater, E. \& Soto Arenas, M.A. (eds.) (2003) Icones orchidacearum 5-6: Orchids of Mexico 2-3. Herbario AMO, Mexico, D.F., pp. 680-695.

Hagsater, E. \& Soto Arenas, M.A. (eds.) (2008) Icones orchidacearum 10: Orchids of Mexico 4. Herbario AMO. Mexico, D.F., pp. $1095-1098$.

Lindley, J. (1837) Notes upon some genera and species of American Orchidaceae, part 1. Companion to the Botanical Magazine 2: 353-357.

Lindley. J. (1840) Miscellaneous notices. Edward's Botanical Register 26: 1-90.

Lindley, J. (1859). Pleurothallis. Folia orchidacea Matthews, London, pp. 1-46.

Linnaeus, C. (1763) Species plantarum, tomus II, 2nd edition. Salvii, Stockholm, 560 pp.

Luer, C.A. (1986) Icones pleurothallidinarum 1: Systematics of Pleurothallis. Monographs in Systematic Botany from Missouri Botanical Garden 15: 1-81.

Luer, C.A. (2007) Icones pleurothallidinarum 29: A third century of Stelis of Ecuador. Systematics of Apoda-Prorepentia. Monographs in Systematic Botany from Missouri Botanical Garden 112: 1-130.

Luer, C.A. (2009) Icones pleurothallidinarum 30: Lepanthes of Jamaica. Systematics of Stelis. Stelis of Ecuador, part four. Systematics of Masdevallia, new species from Ecuador and miscellaneous new combinations. Monographs in Systematic Botany from Missouri Botanical Garden 115: 1-260.

Pridgeon, A.M. \& Chase, M.W. (2001) A phylogenetic reclassification of Pleurothallidinae (Orchidaceae). Lindleyana 16: 235-271.

Pridgeon, A.M. \& Chase, M.W. (2002) Nomenclatural notes on Pleurothallidinae (Orchidaceae). Lindleyana 17: $98-101$.

Pridgeon, A.M., Solano-Gomez, R. \& Chase, M.W. (2001) Phylogenetic relationships in Pleurothallidinae (Orchidaceae): combined evidence from nuclear and plastid DNA sequences. American Journal of Botany 88: 2286-2308. http://dx.doi.org/10.2307/3558390

Pridgeon, A.M., Cribb, P.J., Chase, M.W. \& Rasmussen, F.N. (eds.). (2005). Genera orchidacearum, vol. 4: Epidendroideae (part one). Oxford University Press, Oxford, $672 \mathrm{pp}$.

Pupulin, F. (2002) Catalogo revisado y anotado de las Orchidaceae de Costa Rica. Lankesteriana 2: 1-88.

Ramos-Castro, S.E., Castañeda-Zarate, M., Solano, R., \& Salazar, G.A. (2012) Stelis zootrophionoides (Orchidaceae: Pleurothallidinae), a new species from Mexico. PLoS ONE 7: e48822.

http://dx.doi.org/10.1371/journal.pone.0048822 
Schlechter, F.R.R. (1923) Beitrage zur orchideenkunde von Zentralamerika II. Additamenta ad orchideologiam costaricensem. Repertorium Specierum Novarum Regni Vegetabilis, Beihefte 19: 1-307.

Solano, R. (1993) El género Stelis Sw. (Orchidaceae: Pleurothallidinae) en Mexico. Orquidea (Mexico City) n.s. $13: 1-112$.

Solano, R. (2000) Additions to Stelis Sw. (Pleurothallidinae) from Mexico. Lindleyana 15: 49-52.

Solano, R. (2010). Dos especies nuevas de Pleurothallidinae (Orchidaceae) para Mexico. Lankesteriana 9: 447-454.

Solano, R. (2011) Three new species of Stelis (Orchidaceae) for Mexico. Brittonia 63: 325-333. http://dx.doi.org/10.1007/s12228-010-9171-z

Solano, R. \& Salazar, G.A. (2007) A new species of Stelis (Orchidaceae: Pleurothallidinae) from Guerrero, Mexico. Revista Mexicana de Biodiversidad 78: 253-256.

Soto Arenas, M.A., Solano, R. \& Hagsater, E. (2007) Risk of extinction and patterns of diversity loss in Mexican orchids. Lankesteriana 7: 114-121.

Soto Arenas, M.A, Hagsater, E., Salazar, G.A. Jimenez Machorro, R., Solano, R., Flores, R. \& Ruiz, I. (2007) Las orquideas de Mexico, catalogo digital. Instituto Chinoin, Mexico, D.F.

Swartz, O. (1799) Dianome Epidendri generis. Journal für die Botanik 2: 201-244.

Swartz, O. (1799) Dendrobium. Nova Acta Regiae Societatis Scientiarum Upsaliensis 6: 82.

Swartz, O. (1799) Lepanthes. Nova Acta Regiae Societatis Scientiarum Upsaliensis 6: 82-85, f. 6.

Szeszko, D.R. (2011) Stelis. In: La orquideoflora mexiquense. Gobierno del Estado de Mexico, Mexico, pp. 358-359.

Thouars, A.A.P. (1822) Histoire particulière des plantes Orchidées recueillies sur les trois îles australes d'Afrique, de France, de Bourbon et de Madagascar. Treuttel et Wurtz, Paris, $150 \mathrm{pp}$, http://dx.doi.org/10.5962/bhl.title.492

Williams, L.O. (1939). Two new combinations. Botanical Museum Leaflets 7: 188. 